\title{
GROUNDWATER DETERIORATION WITH HEAVY METALS IN NORTHEAST CAIRO AREA, EGYPT
}

\author{
Gad, A. ${ }^{(1)}$;Garamoon, H. K. $^{(1)}$; Abd El-Aal, M. H. ${ }^{(2)}$ \\ and Afify, N. M.
}

1) Faculty of Science, Department of Geology, Ain Shams University

2) Faculty of Education, Department of Geophysics.

\begin{abstract}
Groundwater in northeast Cairo is used for drinking, irrigation and industrial purposes. The fast development in this region and its surroundings, as well as the diverse agricultural, industrial and domestic activities, provide many sources of groundwater pollution; such as smelters, industrial effluents, construction debris, and drainage wastes. The pollution leads to deterioration in groundwater quality which affected the human's health, plants and animals. Twenty two groundwater samples from Quaternary aquifer are collected and chemically analyzed to determine the areal distribution of heavy metals concentrations in the area between Anchas and Abu Zaabal at northeast Cairo. The concerned heavy metals include $\mathrm{Cd}, \mathrm{Co}, \mathrm{Cr}, \mathrm{Cu}, \mathrm{Fe}, \mathrm{Mn}, \mathrm{Ni}, \mathrm{Pb}$ and $\mathrm{Zn}$. High concentrations of $\mathrm{Cd}, \mathrm{Co}$ and $\mathrm{Pb}$ are recorded in most of the collected samples.
\end{abstract}

Keywords and Phrases: Groundwater Deterioration, pollution, Heavy Metals, Cluster analysis, Egypt.

\section{INTRODUCTION}

There is a growing consensus among scientists, international organizations and lay persons that water contaminations are endemic environmental issue in fast growing cites. Continuous urbanization of the Nile Delta and surroundings has led to an increase in the contamination of soil and water resources, creating a potential health risk of epic proportions. Due to increasing population density in these areas, groundwater quality is strongly 
influenced by anthropogenic activities (industrial and agricultural activities). Therefore, this groundwater accumulates different types of contaminants from non-point and/or point sources pollution. Nowadays, Egypt is vulnerable to confrontation a serious problem of the shortage in water. Subsequently, the groundwater represents an important source to satisfy the urgent demand for water for different purposes such as drinking, domestic, irrigation and industrial uses.

Geochemical characteristics of groundwater, particularly the levels of heavy metals are significant factors in controlling groundwater usage and for health considerations (Baba and Tayfur, 2011 and Yehia et al., 2017). Assessment of the heavy metals concentrations in groundwater sources is important in protecting the population against toxicity (Yuce et al., 2009). Exposure to very low levels of heavy metals such as lead, chromium, cadmium and mercury have an adverse cumulative effects on human and environment (Carter and Fernando 1979). The dreadful health effects of exposure to these heavy metals are well documented in previous literature in Egypt and worldwide (Dietrich et al., 2004; Salem et al., 2000; Rajappa et al., 2010; Anyakora et al., 2011 and Mousavi et al., 2013).

Owing to industrial and agricultural activities, large amounts of untreated urban municipal, industrial wastewater and rural domestic wastes discharge into the Nile River, canals or agricultural drains which become an easy dumping site for all kinds of wastes (Stahl and Ramadan, 2008). Ismailia Canal represents the most distal downstream of the main Nile River. Thus its water contains all the proceeded pollutants discharged into the Nile. Ismailia 
Canal has many sources of pollution which potentially affects and deteriorates the water quality of the canal (Geriesh et al., 2008; Goher et al., 2014 and Safar et al., 2014).

The present study aims to study the heavy metals contamination levels in the groundwater of the Quaternary aquifers in the northeast Cairo region, as well as, tracking the potential sources of these metals.

\section{MATERIALS AND METHODS}

1 Study Area: The study area lies nearly between Anshas and Abu Zaabal. It is bounded by Longitudes $31^{\circ} 27^{\prime}, 31^{\circ} 67^{\prime} \mathrm{E}$ and Latitudes $30^{\circ} 20^{\prime}, 30^{\circ}$ 46' N (Fig 1). The average temperatures in the study area depend on the time of the year. The highest degrees are recorded in July and August where they reach 38 degree centigrade. The maximum monthly precipitation recorded reached $4 \mathrm{~mm}$ in January and March where the lowest one reached in January and July with a value of zero, so it is considered a dry area (Meteoblue.com 2016).

Several industrial and agricultural activities are recorded in Abu Zabaal and Anshas respectively. The industrial activities in the area include the factory of phosphatic fertilizers, a great number of smelters, National company for metal industries, Mustafa Center for automotive paint, Swissy factory for chemicals, Paper Mill, Mowad Group for manufacture of glass, Chemical plant united for developed industries (Lasheen), Letos factory, Sham textile industries, Sherif factory, Grand bed Egypt factory, Warehouse Rod Line Co., LTD, Aracemco ceramics factory, Egyptian alum factory and Abu Zaabal factory. 
There are many villages located very close to Ismailia canal which constitute potential sources of pollution to surface and groundwater resources.

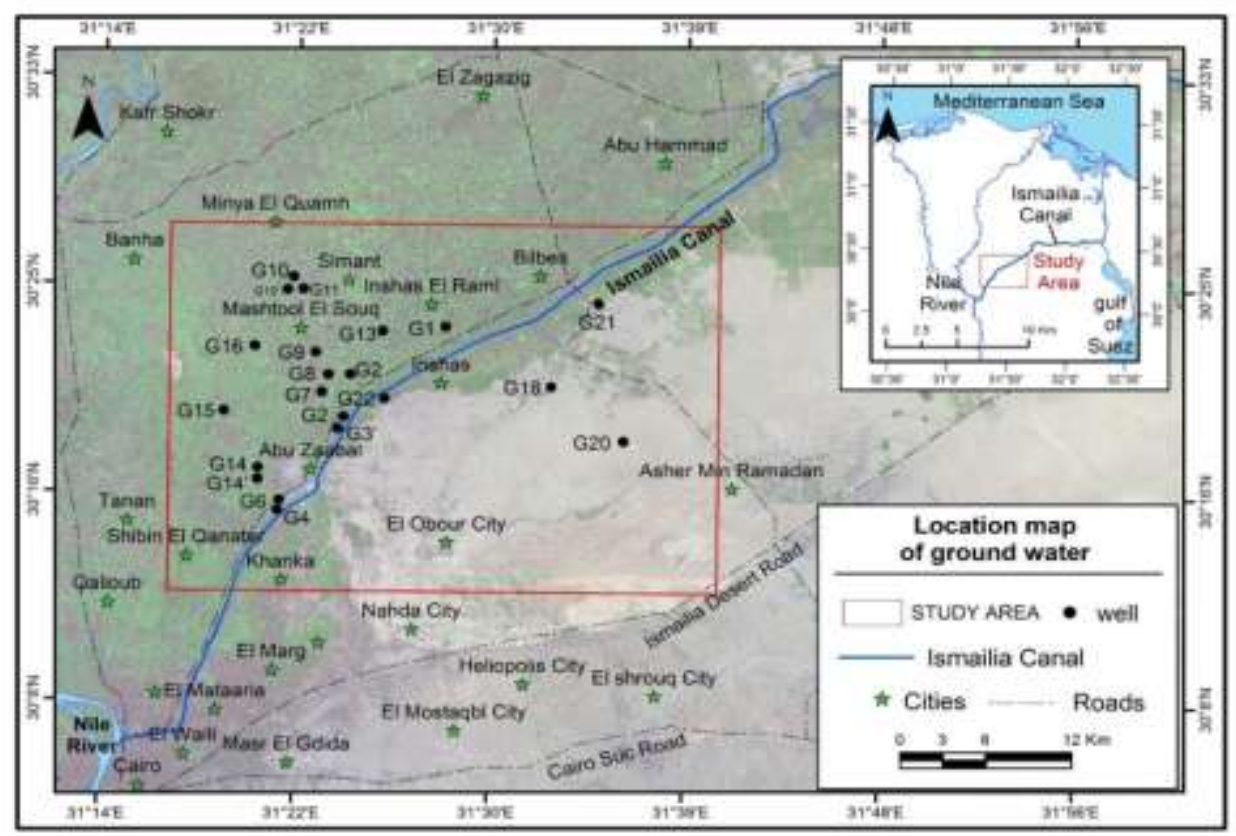

Fig(1): Location map of the study area showing groundwater samples

2 Geologic and Hyrogeologic Settings: The Quaternary sediments which belonging to the Pleistocene and Holocene cover almost all the study area. Basaltic rocks belonging to Upper Oligocene age exposed at Abu Zaabal Quarries while Miocene and Pliocene sediments outcrop at the eastern portions (Fig 2) (RIGW, 1989 and El Fakharany and Mansour, 2009).

The Quaternary aquifer around the Ismailia Canal consists of two hyrogeologic units. The shallow one, especially along the eastern downstream, consists of fine sand and silts mixed with clays and evaporate with thickness varied between 10 and $30 \mathrm{~m}$. The deeper one is of especial 42 
importance for the water supply in the region, which consists of fluviatile deposits forming sequence of loose gravely sands alternating with clay and mud lenses. The thickness of this sequence amounts up to $200 \mathrm{~m}$ along the canal course. The salinity of the groundwater in the shallow aquifer ranges between $340 \mathrm{mg} / \mathrm{l}$ and $7650 \mathrm{mg} / \mathrm{l}$ of $\mathrm{Na}-\mathrm{mix}$ (no dominant anion) to $\mathrm{Na}-\mathrm{Cl}$ type, respectively. The low salinity water is detected in the areas close to the canal course revealing the effect of aquifer recharge by the canal water. The salinity of the deeper aquifer rarely exceeds $1500 \mathrm{mg} / \mathrm{l}$ and is mainly of Namix type. The Quaternary aquifer unconformably overlies the Miocene and Oligocene rocks. Along the western side, Oligocene gravely sands and basaltic sheets are exposed on the surface along the canal enabling external recharge source for the canal water, especially during the winter (Fig 3). The groundwater flow is directed toward the east and northeast and finally discharged into the Suez Canal and its lakes to the east or into the Lake Manzala to the northeastern side (Fig 4) (Geriesh et al., 2008).

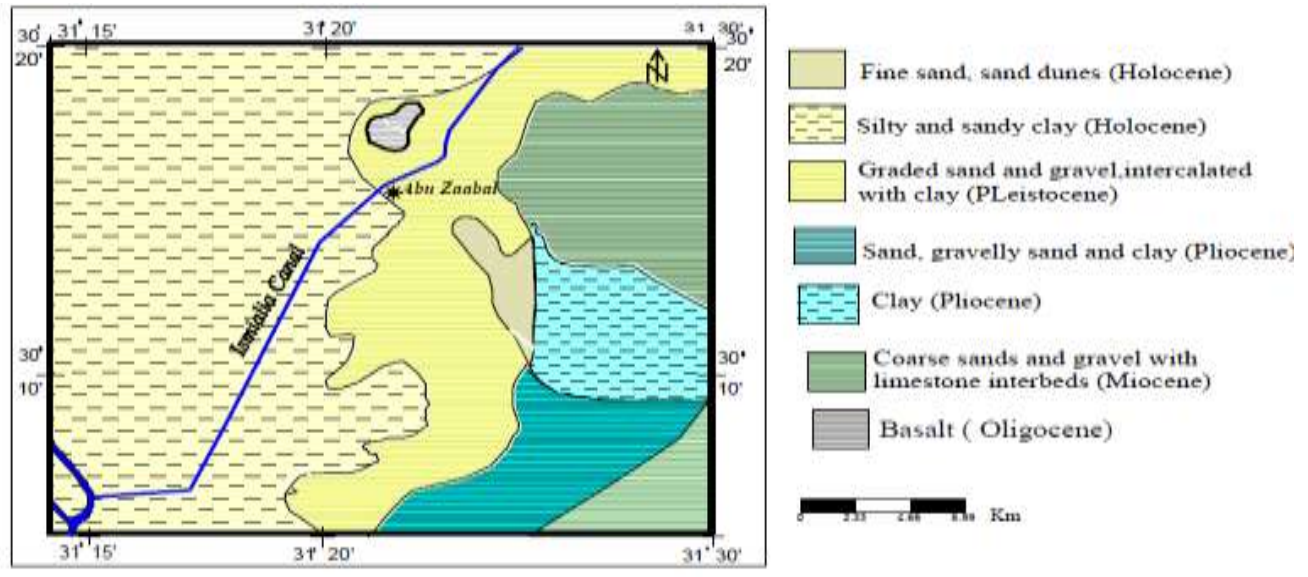

Fig(2): Simplified geologic map of the study area (after RIGW, 1989) 
J. Environ. Sci.

Institute of Environmental Studies and Research - Ain Shams University

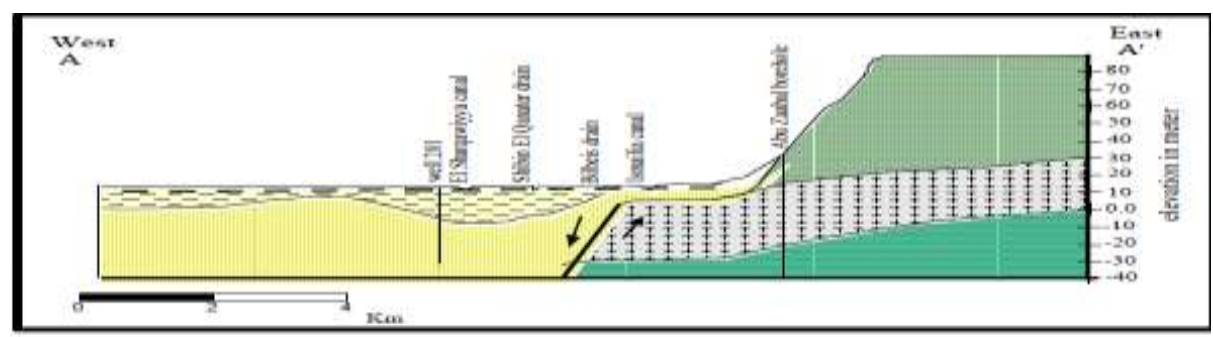

Cross section A

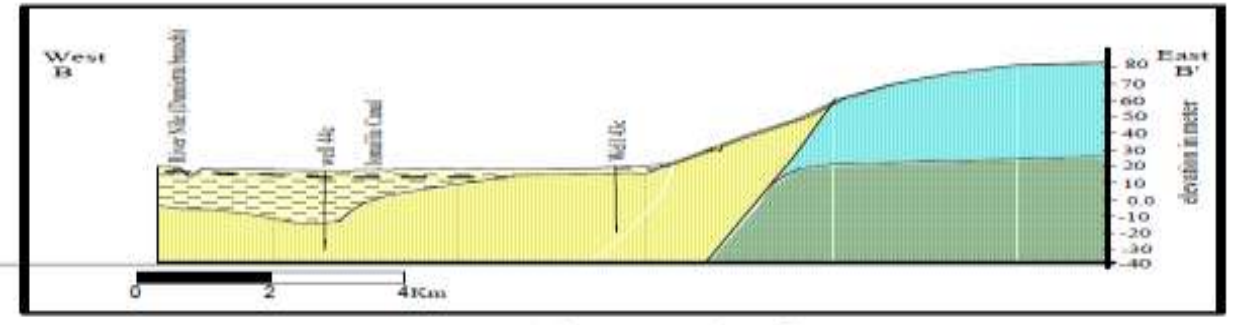

Cross section B

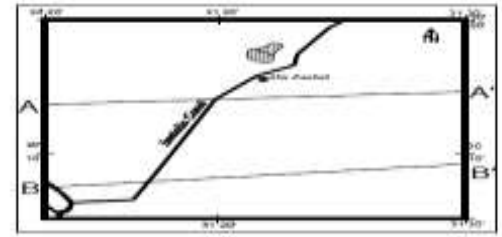

reporid

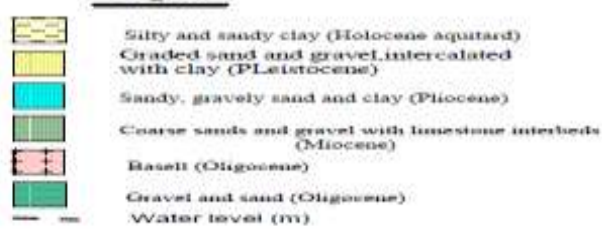

Fig(3): Hydrogeological cross sections at different locations (After RIGW, 1989).

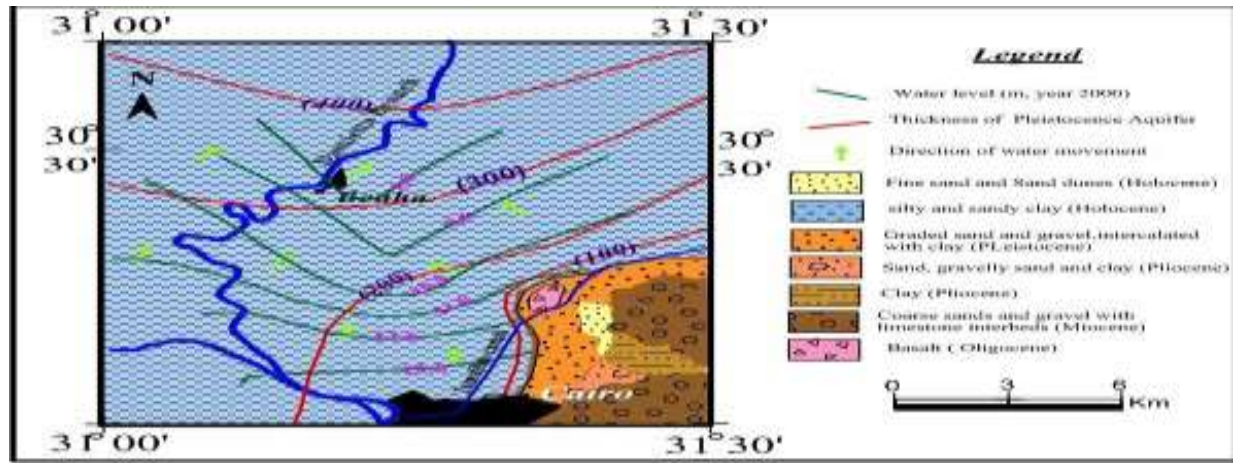

Fig(4): Flow lines of groundwater, the Quaternary aquifer, East Cairo area, Egypt (modified after RIGW 1992; Geriesh et al., 2008). 
3 Sampling: Twenty two groundwater samples are collected from the area of Anshas - Abu Zaabal (Fig 1). The accurate sampling locations were determined using GPS. Samples were collected after 10 min of pumping and were stored in acid-leached polyethylene bottles and preserved by adding ultra-pure nitric acid $(5 \mathrm{~mL} / \mathrm{l})$. Sampling was handled according to the standard methods for examination of water (APHA, 1999).

4 Chemical Analysis: To determine the heavy metals concentrations in groundwater samples, they are filtered by using filtration system through $0.45 \mu \mathrm{m}$-pore-diameter filter paper. Filtration of the groundwater samples aims to minimize the effect of suspended materials on the actual concentration of heavy metals. They are analysed by using of Inductively Coupled Plasma-Optical Emission Spectroscopy (ICP-OES) with ultrasonic Nebulizer (USN). This Nebulizer decrease the instrumental detection limits by 10\%, this ICP instrument is Perkin Elmer Optima 3000, USA.

5 Statistical analysis: In order to exhibit the relationship between heavy metals, correlation coefficients and cluster analysis (CA) are identified using IBM SPSS 20. Correlation coefficient is usually used to establish the relation between independent and dependent variables (Nair et al., 2005).

Cluster analysis is used to group data into hierarchies based on similarities or dissimilarities. There are two types of cluster analysis: R and Q-modes. R-mode was performed on different water quality variables. Qmode cluster analysis was performed on the water chemistry data to group the samples in terms of water quality (Davis, 2002). In the present study, CA was 
applied to group groundwater samples for $\mathrm{Cd}, \mathrm{Cr}, \mathrm{Cu}, \mathrm{Fe}, \mathrm{Mn}, \mathrm{Ni}, \mathrm{Pb}$ and $\mathrm{Zn}$ content.

\section{RESULTS AND DISCUSSION}

1 Metal Distribution: Table (1) shows the concentrations of heavy metals in the study area including $\mathrm{Cd}, \mathrm{Co}, \mathrm{Cr}, \mathrm{Cu}, \mathrm{Fe}, \mathrm{Mn}, \mathrm{Ni}, \mathrm{Pb}$ and $\mathrm{Zn}$. The concentrations of $\mathrm{Cd}, \mathrm{Cr}$ and $\mathrm{Pb}$ range from 0.010 to $0.018,0.065$ to 0.271 and 0.114 to $0.184 \mathrm{ppm}$ respectively. Spatial distributions of the heavy metals concentrations in the groundwater samples of the study area (Figs 5 and 6), shows that the highest values of pollution are recorded at Abu Zabaal region and its vicinity which is characterized by intensive industrial activity.

The concentration of $(\mathrm{Cu})$ in the groundwater of the Quaternary aquifer in the study area ranges from 0.006 to $0.082 \mathrm{ppm}$. The spatial distribution of $(\mathrm{Cu})$ in the collected samples indicate an increase of its concentration in the direction of south Abu Zaabal, but it doesn't exceed the international standards for drinking water. The concentration of $(\mathrm{Ni})$ in the groundwater of the study area ranges from 0.011 to $0.247 \mathrm{ppm}$ and its distribution shows high concentrations in the areas of Abu Zaabal, Mashtool, Tal El Yahoudia, Belbees Road, Shebeen El Qanater, Al Adlya Farm and Anshas, which not far from Abu Zaabal source pollution represented in the intensive industrial activity and inappropriate methods for dumping industrial wastes.

The concentration of $(\mathrm{Zn})$ in the groundwater of the study area ranges from 0.003 to $0.488 \mathrm{ppm}$ and shows relatively high concentration in two samples which lying in Anshas and Abu Zaabal, but within the normal range. 
The concentration of $(\mathrm{Fe})$ ranges from 0.058 to $2.105 \mathrm{ppm}$. The spatial distribution of $(\mathrm{Fe})$ shows high concentrations in regions of Anshas El Raml, Mashtool and El Adlya, but it exceeds the standard just in Anshas El Raml (2.105 ppm). The concentration of ( $\mathrm{Mn})$ in the groundwater of the study area ranges from 0.007 to $1.063 \mathrm{ppm}$. The distribution of $(\mathrm{Mn})$ in the groundwater of the study area shows several high concentrations such as in G1, G9, G11 and G16, while it exceeds limit only in Anshas El Raml (Figures 5 and 6). The Co is below detective level in all samples (BDL).

The results show that the duplication ratio between the recorded concentrations and the international standards varies from about $400 \%$ to $960 \%, 300 \%$ to $600 \%$ and $1200 \%$ to $1700 \%$, for $\mathrm{Cd}, \mathrm{Cr}$ and $\mathrm{Pb}$ respectively.

There are many possible sources of contamination by heavy metals. They include wastes from industrial chemical production, metal plating operations, domestic wastewater and pesticide runoff from agricultural lands. The traditional method of collecting and discharging wastewater using septic tanks lead to wastewater leakage, which severely affect soil and groundwater properties.

Table(1): Concentration of heavy metals in groundwater samples of the study area $(\mathrm{ppm})$

\begin{tabular}{|c|c|c|c|c|c|c|c|c|c|c||}
\hline $\begin{array}{c}\text { Sample } \\
\text { No. }\end{array}$ & Location & $\mathbf{C d}$ & $\mathbf{C o}$ & $\mathbf{C r}$ & $\mathbf{C u}$ & $\mathbf{F e}$ & $\mathbf{M n}$ & $\mathbf{N i}$ & $\mathbf{P b}$ & $\mathbf{Z n}$ \\
\hline \hline G1 & $\begin{array}{c}\text { Anshas El } \\
\text { Raml }\end{array}$ & 0.012 & BDL & 0.176 & 0.024 & 2.105 & 1.063 & 0.014 & 0.148 & 0.115 \\
\hline $\mathbf{G 2}$ & $\begin{array}{c}\text { Mashtool - El } \\
\text { Ghafarya }\end{array}$ & 0.012 & BDL & 0.260 & 0.043 & 0.309 & 0.019 & 0.013 & 0.114 & 0.019 \\
\hline G3 & Al Monier & 0.013 & BDL & 0.143 & 0.006 & 0.058 & 0.032 & 0.011 & 0.136 & 0.003 \\
\hline G3 & Al Monier & 0.012 & BDL & 0.092 & 0.032 & 0.379 & 0.026 & 0.010 & 0.128 & 0.012 \\
\hline G4 & $\begin{array}{c}\text { Abu Zaabal } \\
\text { (fawzy Farm) }\end{array}$ & 0.014 & BDL & 0.188 & 0.295 & 0.188 & 0.038 & 0.020 & 0.170 & 0.272 \\
\hline
\end{tabular}


J. Environ. Sci.

Institute of Environmental Studies and Research - Ain Shams University

Cont. Table(1):

\begin{tabular}{|c|c|c|c|c|c|c|c|c|c|c|}
\hline $\begin{array}{l}\text { Sampl } \\
\text { e No. }\end{array}$ & Location & Cd & Co & $\mathrm{Cr}$ & $\mathbf{C u}$ & $\mathrm{Fe}$ & Mn & $\mathbf{N i}$ & $\mathbf{P b}$ & $\mathbf{Z n}$ \\
\hline G6 & $\begin{array}{c}\text { Abu Zabal } \\
\text { Maqaber }\end{array}$ & 0.014 & BDL & 0.271 & 0.064 & 0.271 & 0.048 & 0.041 & 0.151 & 0.052 \\
\hline G7 & $\begin{array}{c}\text { Mashtool } \\
\text { (Usama Farm) }\end{array}$ & 0.010 & BDL & 0.160 & 0.020 & 0.409 & 0.035 & 0.023 & 0.125 & 0.011 \\
\hline G8 & Mastool & 0.012 & BDL & 0.224 & 0.014 & 0.466 & 0.240 & 0.011 & 0.127 & 0.066 \\
\hline G9 & Mashtool & 0.014 & BDL & 0.236 & 0.016 & 0.530 & 0.300 & 0.015 & 0.134 & 0.005 \\
\hline G10 & $\begin{array}{l}\text { Mashtool (Kafr } \\
\text { Ebrash) }\end{array}$ & 0.017 & BDL & 0.169 & 0.037 & 0.169 & 0.101 & 0.016 & 0.146 & 0.063 \\
\hline G10' & $\begin{array}{c}\text { Mashtool } \\
\text { (Kafr } \\
\text { Ebrash) }\end{array}$ & 0.013 & BDL & 0.110 & 0.155 & 0.110 & 0.297 & 0.014 & 0.137 & 0.086 \\
\hline G11 & $\begin{array}{c}\text { Mashtool (Kafr } \\
\text { Ebrash) }\end{array}$ & 0.013 & BDL & 0.153 & 0.020 & 0.153 & 0.522 & 0.018 & 0.133 & 0.020 \\
\hline G13 & $\begin{array}{c}\text { Meniat } \\
\text { Salamant }\end{array}$ & 0.013 & BDL & 0.133 & 0.041 & 0.133 & 0.069 & 0.010 & BDL & 0.028 \\
\hline G14 & $\begin{array}{c}\text { Tal El } \\
\text { Yahodya }\end{array}$ & 0.017 & BDL & 0.215 & 0.017 & 0.215 & 0.029 & 0.033 & 0.161 & 0.040 \\
\hline G14' & $\begin{array}{c}\text { Tal El } \\
\text { Yahodya }\end{array}$ & 0.014 & BDL & 0.118 & 0.082 & 0.751 & 0.021 & 0.018 & 0.127 & 0.020 \\
\hline G15 & $\begin{array}{c}\text { Shebeen El } \\
\text { Qanater } \\
\text { (AlAhwaz) }\end{array}$ & 0.015 & BDL & 0.065 & 0.100 & 0.566 & 0.389 & 0.022 & 0.133 & 0.020 \\
\hline G16 & $\begin{array}{c}\text { Shebeen } \\
\text { Elqanater(Kafr } \\
\text { Saad Behairy) } \\
\end{array}$ & 0.014 & BDL & 0.091 & 0.060 & 0.539 & 0.396 & 0.017 & 0.127 & 0.032 \\
\hline G18 & Belbees Road & 0.015 & BDL & 0.156 & 0.015 & 0.302 & 0.010 & 0.026 & 0.165 & 0.007 \\
\hline G19 & $\begin{array}{l}\text { Dr Ayman El } \\
\text { Hadidy Farm }\end{array}$ & 0.018 & 0.001 & 0.313 & 0.012 & 0.747 & 0.012 & 0.042 & 0.165 & 0.022 \\
\hline G20 & $\begin{array}{l}\text { El Adlia } \\
\text { Farm }\end{array}$ & 0.018 & BDL & 0.385 & 0.013 & 0.139 & 0.013 & 0.047 & 0.163 & 0.026 \\
\hline G21 & $\begin{array}{c}\text { Belbees Air } \\
\text { Base }\end{array}$ & 0.013 & BDL & 0.105 & 0.019 & 0.124 & 0.007 & 0.015 & 0.127 & 0.023 \\
\hline G22 & Anshas & 0.014 & BDL & 0.252 & 0.025 & 0.529 & 0.112 & 0.027 & 0.153 & 0.488 \\
\hline $\begin{array}{c}\text { Drinki } \\
\text { ng } \\
\text { Water } \\
\text { MAC }\end{array}$ & & 0.003 & $\mathrm{NM}$ & 0.05 & 2 & 1 & 0.5 & 0.02 & 0.01 & 3 \\
\hline
\end{tabular}

BDL $=$ below detection limit, $\mathrm{NM}=$ Not mentioned, MAC $=$ Maximum allowable limit, *= WHO (2011) 


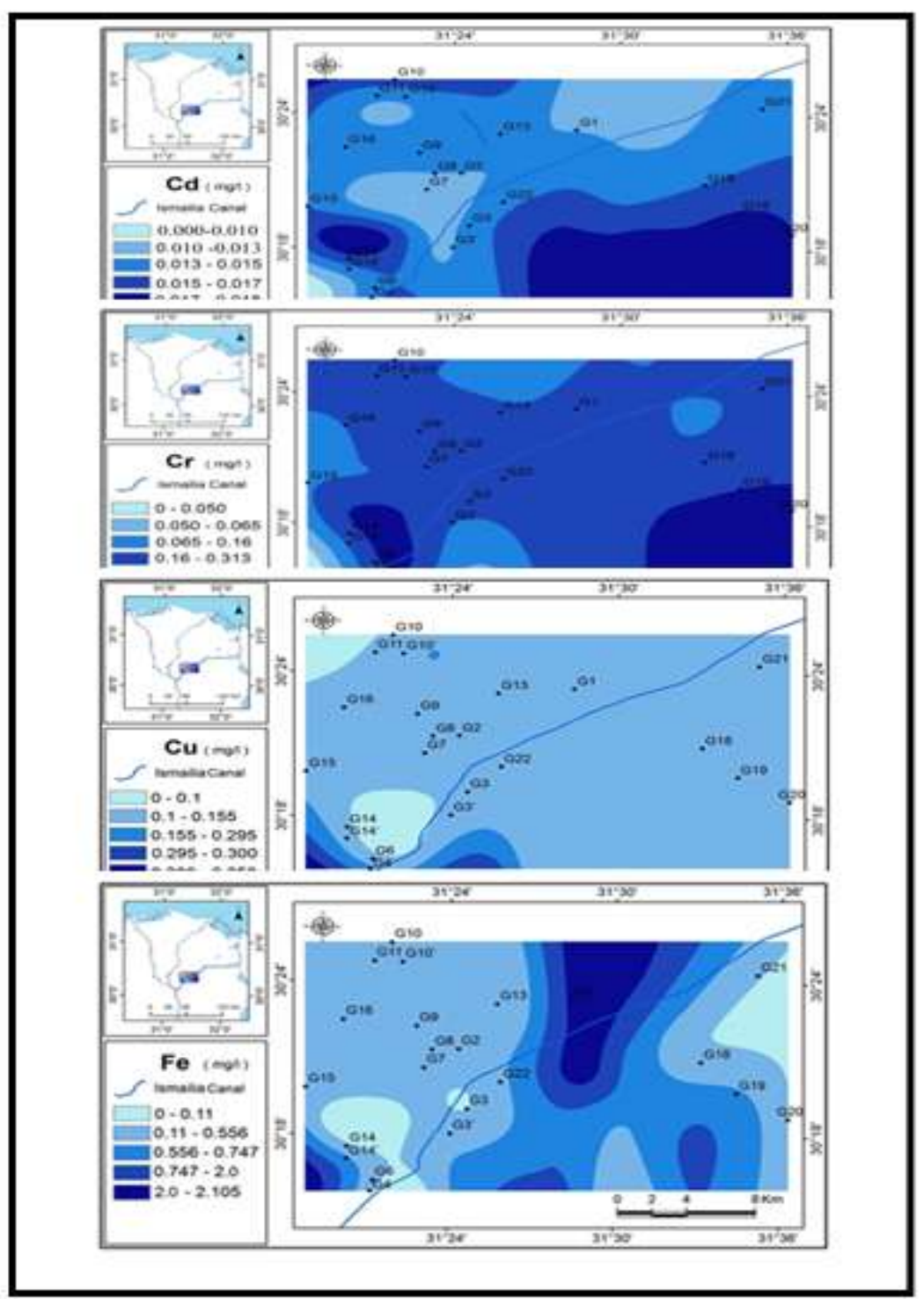

Fig.(5): Concentrations of $\mathrm{Cd}, \mathrm{Cr}, \mathrm{Cu}$ and $\mathrm{Fe}$ in the groundwater of the study area 
J. Environ. Sci.

Institute of Environmental Studies and Research - Ain Shams University

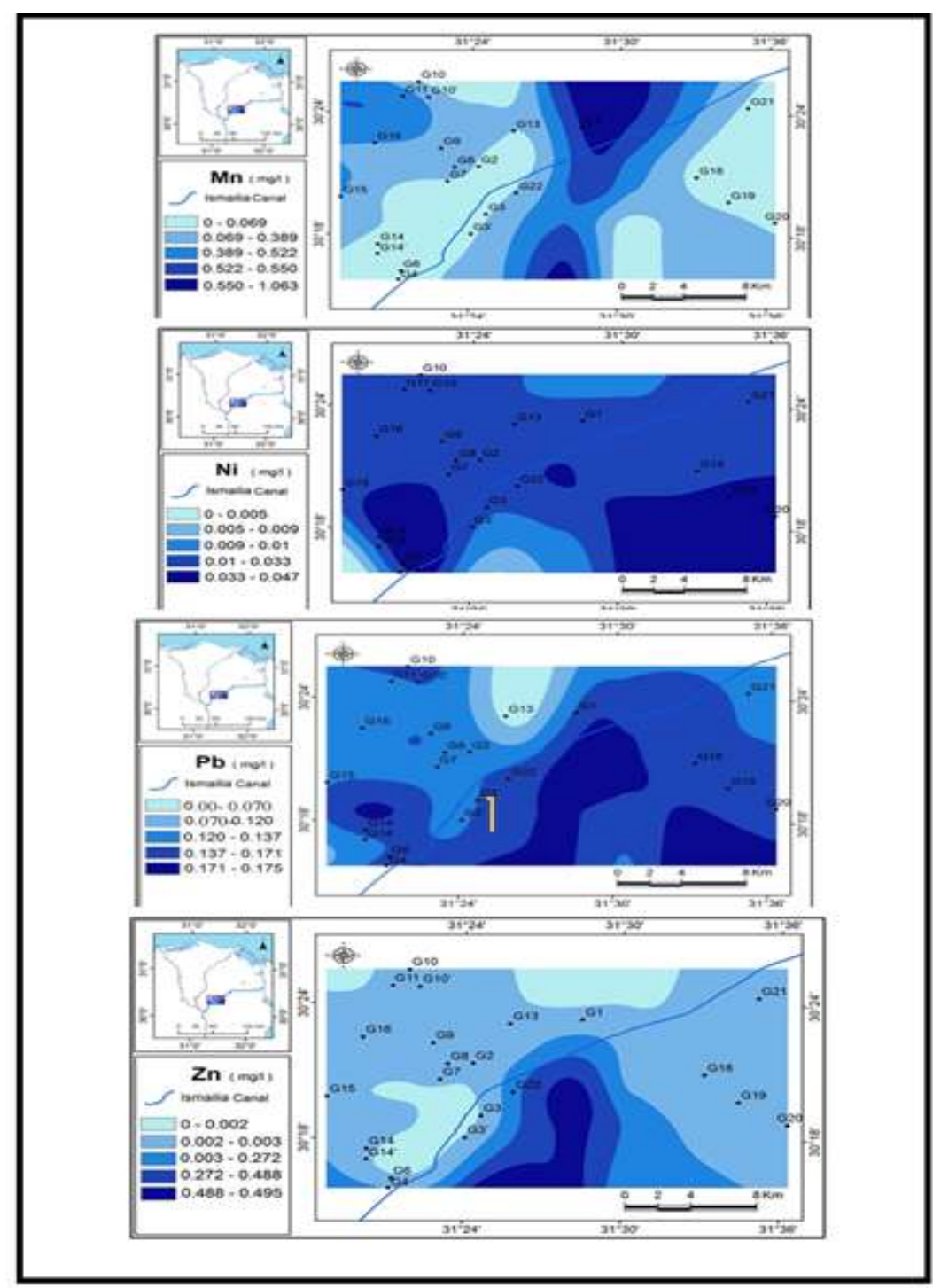

Fig.(6): Concentrations of $\mathrm{Mn}, \mathrm{Ni}, \mathrm{Pb}$ and $\mathrm{Zn}$ in the groundwater of the study area 
2 Suitability of Groundwater for drinking: A comparison with several local and international standards and guidelines for drinking water has been done to evaluate heavy metals content in groundwater to show its suitability for drinking (Table 2).

Table(2): Suitability of Groundwater for drinking and duplication ratio based on heavy metals content

\begin{tabular}{|c|c|c|c|c|c|c||}
\hline Metal & $\begin{array}{c}\text { ESDW, } \\
\mathbf{( 2 0 0 7 )}\end{array}$ & $\begin{array}{c}\text { WHO, } \\
\mathbf{( 2 0 1 1 )}\end{array}$ & $\begin{array}{c}\text { ADWG, } \\
\mathbf{( 2 0 1 1 )}\end{array}$ & $\begin{array}{c}\text { Samples } \\
\text { Exceed }\end{array}$ & $\begin{array}{c}\text { Percentage } \\
\text { \% }\end{array}$ & $\begin{array}{c}\text { Duplication } \\
\text { Ratio to } \\
\text { WHO } \\
\text { standards }\end{array}$ \\
\hline \hline $\mathrm{Cd}$ & & 0.003 & & $\begin{array}{c}\text { All } \\
\text { Samples }\end{array}$ & $100 \%$ & $400-960 \%$ \\
\hline $\mathrm{Cr}$ & 0.05 & 0.05 & 0.05 & All samples & $100 \%$ & $300-600 \%$ \\
\hline $\mathrm{Cu}$ & 2 & 2 & 2 & ------ & ------ & ------- \\
\hline $\mathrm{Fe}$ & 0.3 & 1 & 0.3 & G 1 & $4.3 \%$ & $200 \%$ \\
\hline $\mathrm{Mn}$ & 0.4 & 0.5 & 0.4 & $\begin{array}{c}\text { G1 and } \\
\text { G11 }\end{array}$ & $9 \%$ & $300 \%$ \\
\hline $\mathrm{Ni}$ & 0.02 & 0.02 & 0.02 & 8 samples & $36.3 \%$ & $35-100 \%$ \\
\hline $\mathrm{Pb}$ & 0.01 & 0.01 & 0.01 & $\begin{array}{c}\text { Most } \\
\text { samples }\end{array}$ & $95.4 \%$ & $1200-1700 \%$ \\
\hline $\mathrm{Zn}$ & 3 & 3 & 3 & ------ & ------ & ----- \\
\hline
\end{tabular}

Groundwater samples of the study area contain high concentrations of heavy metals that exceed the recommended limits in drinking water particularly for $\mathrm{Cd}, \mathrm{Cr}$ and $\mathrm{Pb}$, where they exceed the recommended limits in $100 \%, 100 \%$ and $95.4 \%$ of the studied samples, respectively. $\mathrm{Cu}, \mathrm{Fe}, \mathrm{Mn}, \mathrm{Ni}$ and $\mathrm{Zn}$ don't exceed the recommended limits in all samples, while Co is below the detective limit.

3 Comparison with different parts of the Nile Delta: A comparison between the concentrations of heavy metals in the groundwater of the present study and those of other areas are shown in Table (3). The comparison revealed that the groundwater of the study area contains higher 
concentrations of lead and Chromium which may be assigned to the intensive industrial activity of Abu Zaabal region and its surroundings. So, it can be said that the groundwater of the study area is heavily polluted with lead and Chromium that it is not suitable for drinking.

Table(3): A Comparisons between maximum concentrations of heavy metals in the study area and those in different parts of the Nile Delta.

\begin{tabular}{|c|c|c|c|c|c|c|c|c|c|}
\hline \multirow{2}{*}{ Location } & \multicolumn{8}{|c|}{ Heavy Metals Maximum Concentration (ppm) } & \multirow{2}{*}{$\begin{array}{c}\text { Referenc } \\
\mathrm{e} \\
\end{array}$} \\
\hline & Cd & Co & $\mathbf{C r}$ & $\mathbf{C u}$ & $\mathbf{F e}$ & Mn & $\mathrm{Ni}$ & $\mathbf{P b}$ & \\
\hline $\begin{array}{c}\text { Anshas - } \\
\text { Abu Zaabal }\end{array}$ & 0.018 & $\mathrm{BDL}$ & 0.385 & 0.82 & $\begin{array}{c}2.10 \\
5\end{array}$ & 1.063 & $\begin{array}{c}0.24 \\
7\end{array}$ & $\begin{array}{c}0.18 \\
4\end{array}$ & $\begin{array}{l}\text { Present } \\
\text { study }\end{array}$ \\
\hline $\begin{array}{l}\text { Northwester } \\
\mathrm{n} \text { Part of } \\
\text { the Nile } \\
\text { Delta }\end{array}$ & 0.710 & ------ & 0.045 & 1.895 & $\begin{array}{c}4.20 \\
0\end{array}$ & 0.821 & $\begin{array}{c}0.58 \\
0\end{array}$ & $\begin{array}{c}0.02 \\
0\end{array}$ & $\begin{array}{c}\text { Awad et } \\
\text { al. } \\
(2015)\end{array}$ \\
\hline $\begin{array}{c}\text { Dakahlyia } \\
\text { Governorate }\end{array}$ & 0.003 & ------ & 0.004 & 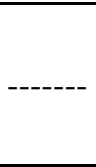 & $\begin{array}{c}0.08 \\
5\end{array}$ & 0.023 & $\begin{array}{c}0.02 \\
3\end{array}$ & $\begin{array}{c}0.00 \\
9\end{array}$ & $\begin{array}{c}\text { Mandour } \\
\text { and } \\
\text { Azab } \\
(2010)\end{array}$ \\
\hline $\begin{array}{l}\text { Southeast } \\
\text { Nile Delta }\end{array}$ & $\begin{array}{c}0.000 \\
7\end{array}$ & $\begin{array}{c}0.000 \\
9\end{array}$ & $\begin{array}{c}0.021 \\
5\end{array}$ & $\begin{array}{c}0.033 \\
2\end{array}$ & $\begin{array}{c}2.63 \\
3\end{array}$ & $\begin{array}{c}0.086 \\
4\end{array}$ & $\begin{array}{c}0.00 \\
3\end{array}$ & $\begin{array}{c}0.01 \\
4\end{array}$ & $\begin{array}{c}\text { Khalaf } \\
\text { and Gad } \\
(2015) \\
\end{array}$ \\
\hline East Delta & BDL & $\mathrm{BDL}$ & $\begin{array}{c}0.030 \\
8\end{array}$ & $\begin{array}{c}0.229 \\
3\end{array}$ & $\begin{array}{c}0.50 \\
9\end{array}$ & $\begin{array}{c}0.208 \\
7\end{array}$ & $\begin{array}{c}0.01 \\
1\end{array}$ & BDL & $\begin{array}{c}\text { GAD et } \\
\text { al. } \\
(2015)\end{array}$ \\
\hline $\begin{array}{l}\text { Western } \\
\text { Nile Delta }\end{array}$ & $\begin{array}{c}0.004 \\
0\end{array}$ & -- & 0.046 & 0.100 & 4.20 & 0.40 & $\begin{array}{c}3.10 \\
0\end{array}$ & $\begin{array}{c}0.00 \\
5\end{array}$ & $\begin{array}{c}\text { Sharaky } \\
\text { et al. } \\
(2007)\end{array}$ \\
\hline $\begin{array}{l}\text { Southeast } \\
\text { Nile Delta }\end{array}$ & 0.097 & ------- & $\ldots$ & 0.760 & $\begin{array}{c}0.53 \\
1\end{array}$ & 0.58 & ------ & $\begin{array}{c}0.14 \\
8\end{array}$ & $\begin{array}{c}\text { Taha et } \\
\text { al. } \\
\text { (2004) }\end{array}$ \\
\hline
\end{tabular}

4 Potential Sources of Pollution with Heavy Metals: Recently, the industrial activities attract attention of many authors as point and non-point pollution sources in this area. The industrial area of Abu Zaabal and its 
surroundings may constitute a primary source of pollution of surface water with heavy metals which may infiltrate to the groundwater (Table 4).

Table(4): Metal concentrations related to industrial activities in the study area

\begin{tabular}{|c|c|c|c|c|c|c|c|c|c|c|c|}
\hline \multirow{2}{*}{ Location } & \multirow{2}{*}{$\begin{array}{l}\text { Type of } \\
\text { Sanple }\end{array}$} & \multicolumn{9}{|c|}{ Hean Mehals Yarinun Coacentrativa } & \multirow{2}{*}{ Rétereace } \\
\hline & & $\mathrm{Cd}$ & $\mathrm{C}_{0}$ & $\mathrm{Cr}_{\mathrm{r}}$ & Cu & $\mathrm{Fe}$ & In & $\mathrm{Si}_{\mathrm{i}}$ & $\mathrm{Pb}$ & Zn & \\
\hline \multirow{2}{*}{ Aratla Lead Smeter } & $B=$ Dest & $\begin{array}{l}950 \\
\mathrm{mghg} \\
\end{array}$ & - & $\begin{array}{l}33808 \\
\text { mgly }\end{array}$ & - & - & - & - & $\begin{array}{c}78265000 \\
\mathrm{mghg}\end{array}$ & $\begin{array}{l}669150 \\
\text { mghg }\end{array}$ & \multirow{2}{*}{$\frac{\text { Saftet al }}{214}$} \\
\hline & Sollsuple & $\begin{array}{l}325 \\
\text { mgly }\end{array}$ & - & $\mathrm{SD}$ & - & - & - & - & $\begin{array}{l}5350 \\
\mathrm{mgh}\end{array}$ & $\begin{array}{l}\text { B9 } \\
\text { mgkg }\end{array}$ & \\
\hline $\begin{array}{l}\text { Besidelead } \\
\text { Imater }\end{array}$ & Dust & $\begin{array}{l}5.98 \\
\operatorname{sgg}\end{array}$ & $\begin{array}{l}262 \\
199\end{array}$ & $\begin{array}{l}957 \\
195\end{array}$ & - & - & - & $\begin{array}{r}9075 \\
135\end{array}$ & $\begin{array}{l}1102 \\
\operatorname{lgg}\end{array}$ & $\begin{array}{c}31152 \\
\operatorname{lgg}\end{array}$ & Alietal 2011 \\
\hline $\begin{array}{c}\text { Centul of Ahn } \\
\text { Zantal }\end{array}$ & Dast & $\begin{array}{l}395 \\
195\end{array}$ & $\begin{array}{l}199 \\
\operatorname{lgg}\end{array}$ & $\begin{array}{l}2609 \\
\mathrm{Hg}\end{array}$ & - & - & - & $\begin{array}{l}415 \\
195\end{array}$ & $\begin{array}{l}112 \\
\text { gag }\end{array}$ & $\begin{array}{l}175.47 \\
195\end{array}$ & Alietal 2011 \\
\hline $\begin{array}{c}\text { Wol Easten } \\
\text { of fertiner } \\
\text { plant }\end{array}$ & Dast & $\begin{array}{l}16.69 \\
195\end{array}$ & $\begin{array}{l}533 \\
199\end{array}$ & $\begin{array}{l}6984 \\
159\end{array}$ & - & - & - & $\begin{array}{l}7874 \\
195\end{array}$ & $\begin{array}{l}4975 \\
159\end{array}$ & $\begin{array}{l}786.4 \\
195\end{array}$ & Alited 2011 \\
\hline $\begin{array}{c}\text { In frect of Alsu Zabal } \\
\text { factory }\end{array}$ & Sefinet & $\begin{array}{l}0.9 \\
\mathrm{En}\end{array}$ & $\begin{array}{l}312 \\
\mathrm{FE}\end{array}$ & - & $\begin{array}{l}37.11 \\
\mathrm{pmm} \\
\end{array}$ & - & 203 & $\begin{array}{l}33.4 \\
\text { pan } \\
\end{array}$ & $\begin{array}{l}37.15 \\
\text { HFW }\end{array}$ & $\begin{array}{l}158 \\
\mathrm{Fan}\end{array}$ & $\begin{array}{c}\text { Norretal, } \\
2013\end{array}$ \\
\hline $\begin{array}{l}\text { Dischagegpint of } \\
\text { Kar Ptuden } \\
\text { Conquy }\end{array}$ & $\begin{array}{l}\text { Sufface } \\
\text { Water }\end{array}$ & & ND. & $\begin{array}{l}0.053 \\
\mathrm{gen}\end{array}$ & 0.58 & $\begin{array}{l}2.608 \\
\mathrm{Fm}\end{array}$ & - & - & $\begin{array}{l}0.166 \\
175\end{array}$ & $\frac{0.80}{7 F+}$ & $\frac{\text { Kanllitedi, }}{2012}$ \\
\hline 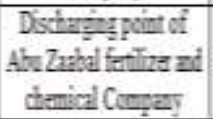 & $\begin{array}{l}\text { Sufface } \\
\text { Wate }\end{array}$ & - & ND. & $\begin{array}{l}0.092 \\
\text { gen }\end{array}$ & $\begin{array}{l}8392 \\
\mathrm{pmm}\end{array}$ & $\begin{array}{l}3199 \\
\mathrm{Frn}\end{array}$ & - & - & $\begin{array}{l}0.234 \\
17 m\end{array}$ & $\begin{array}{l}0.234 \\
\mathrm{Fen}\end{array}$ & $\frac{\text { Khplilet }}{2012}$ \\
\hline
\end{tabular}

5 Statistical analysis: The groundwater samples are used for the correlation coefficient and cluster analyses. Significant positive correlations between $\mathrm{Cd}$ and $\mathrm{Cr}$ (0.451), $\mathrm{Cd}$ and $\mathrm{Ni}$ (0.675), $\mathrm{Cr}$ and $\mathrm{Ni}$ (0.692), Fe and $\mathrm{Mn}(0.726)$ and between $\mathrm{Ni}$ and $\mathrm{Pb}(0.509)$ are recorded (Table 5). Co was excluded due to it is not detected in more than $50 \%$ of the samples.

The results of cluster analysis (CA) are performed in Ward's method (Fig. 7). The dendrogram exhibits two groups of clusters Cluster 1 (Fe, Mn, $\mathrm{Cu}$ and $\mathrm{Zn})$ and Cluster $2(\mathrm{Cr}, \mathrm{Ni}, \mathrm{Cd}$ and $\mathrm{Pb})$. 
The significant positive correlation between $\mathrm{Cd}, \mathrm{Cr}, \mathrm{Ni}$ and $\mathrm{Pb}$ and the clustering of these heavy metals in one group indicating the anthropogenic source of contamination in the studied groundwater (Moore et al., 2011).

Table(5): Correlation matrix of the heavy metals for the study area

\begin{tabular}{|c|c|c|c|c|c|c|c|c|}
\hline & Cd & $\mathrm{Cr}$ & $\overline{\mathrm{Cu}}$ & Fe & Mn & $\mathbf{N i}$ & $\mathbf{P b}$ & $\mathbf{Z n}$ \\
\hline $\mathrm{Cd}$ & 1 & $.451 *$ & -.042 & -.148 & -.248 & $.675 * *$ & .406 & -.007 \\
\hline $\mathrm{Cr}$ & & 1 & -.219 & .005 & -.218 & $.692 * *$ & .345 & .183 \\
\hline $\mathrm{Cu}$ & & & 1 & -.127 & -.026 & -.098 & .127 & .352 \\
\hline $\mathrm{Fe}$ & & & & 1 & $.726^{* *}$ & -.059 & .139 & .121 \\
\hline $\mathrm{Mn}$ & & & & & 1 & -.281 & .021 & .051 \\
\hline $\mathrm{Ni}$ & & & & & & 1 & $.509 *$ & .076 \\
\hline $\mathrm{Pb}$ & & & & & & & 1 & .234 \\
\hline $\mathrm{Zn}$ & & & & & & & & 1 \\
\hline \multicolumn{9}{|c|}{ *. Correlation is significant at the 0.05 level (2-tailed). } \\
\hline & & & & 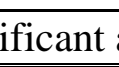 & the 0.0 & ovel (? & led). & \\
\hline
\end{tabular}

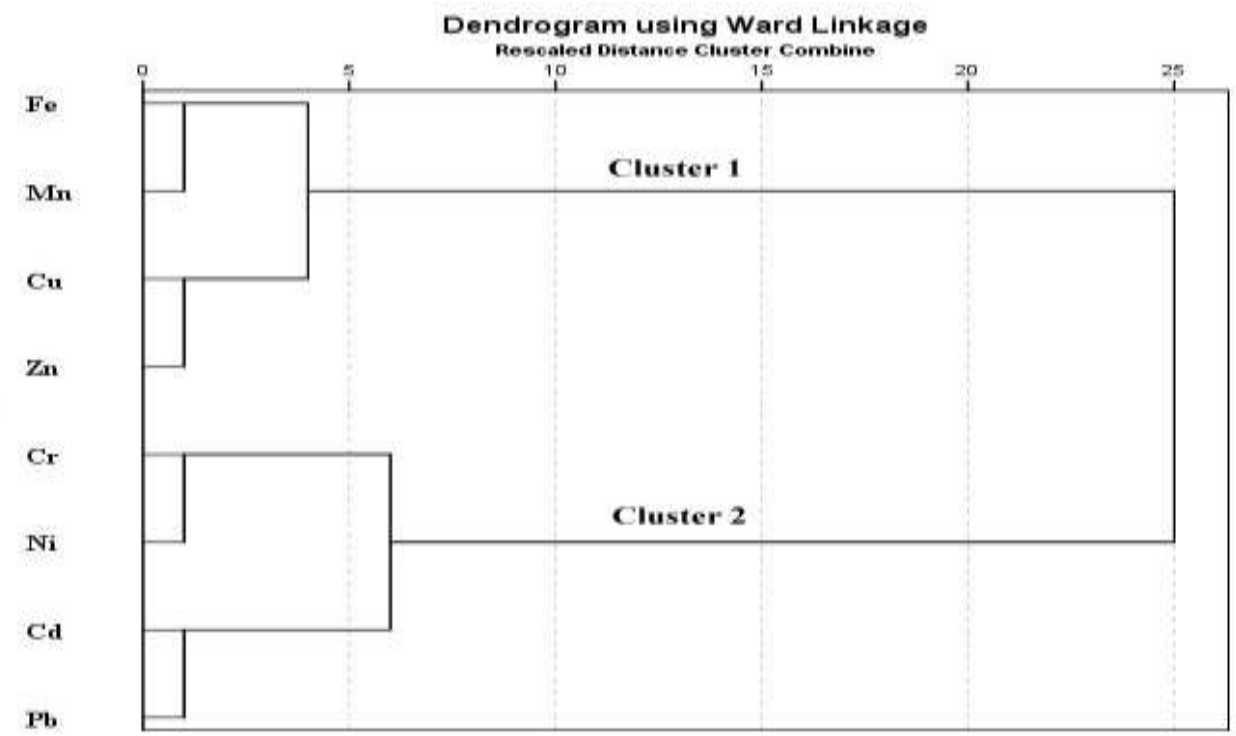

Fig(7): Dendogram for 8 variables from cluster analysis in R-mode 


\section{CONCLUSION}

The concentrations of the heavy metals of the area between Anshas and Abu Zaabal, northeast Cairo, reflect the following results; the concentrations of Cadmium, Chromium and Lead in most samples are exceeding the international standards. The increase of concentration of heavy metals reflects an increase of pollution in the study area due to mainly industrial activities (Table 4). Most samples of groundwater have concentrations exceeding the international standards and not valid for drinking due to the high concentrations of these three heavy metals.

\section{RECOMMENDATIONS}

1- Law 48/1982 for the protection of the Nile River and its waterways against pollution must be enforced strictly to prevent the deterioration of water and to improve its quality.

2- Researches are required to complete the picture about the safety of groundwater and surface water of the study area for drinking, irrigation and domestic purposes.

3- Lining irrigation canals and Installing proper drainage and sewage systems in highly populated areas are highly recommended.

4- Using deep penetrated groundwater wells instead of shallow ones where pollution may be less. 


\section{REFERENCES}

Ali, A. A. S., El Taieb, N. M., Hassan, A. M. A., Ibrahim, Y. H. and Abd El Wahab, S. G. (2011). Heavy Metals Enrichment in Deposited Particulate Matter at Abu Zaabal Industrial Area -Egypt. Journal of American Science, 7(8): 347-352.

Anyakora, C., Nwaeze, K., Awodele, O., Chinwe, C., Arbabi, M. and Herbert, C. (2011). Concentrations of heavy metals in some pharmaceutical effluents in Lagos, Nigeria. Journal of Environmental Chemistry and Ecotoxicology, 3(2): 25-31.

APHA (American Public Health Association) (1999). Standard Methods for the Examination of Water and Wastewater, 21th ed. APHA, Washington.

Australian Drinking Water Guidelines (2011) - Updated October 2017. https://www.nhmrc.gov.au/guidelines/publications.

Awad S. R., El Fakharany M. A. and Hagran N. M. (2015). Environmental Impact on Water Resources at the northwestern Part of the Nile Delta, Egypt. Journal of American Science, 11(11): 1-11.

Baba, A. and Tayfur, G. (2011). Groundwater contamination and its effect on health in Turkey. Environmental Monitoring and Assessment, 183, 77-94.

Carter, D.E. and Fernando, Q. (1979). Chemical Toxicology: Part II. Metal toxicity. Journal of Chemical Education, 56(8), 490.

Davis, J.C. (2002). Statistics and Data Analysis in Geology. John Wiley \& Sons Inc., NY.

Dietrich, K., Ware, J., Salganik, M., Radcliffe, J., Walter, J., Rhoads, G., Fay, M., Davoli, C., Denckla, M., Bornschein, R., Schwarz, D., Dockery, D. and Adubato, S. (2004). Effect of chelation therapy on the neuropsychological and behavioral development of leadexposed children after school entry. Pediatrics, 114, 19-26. 
El-Fakharany, M.A. and Mansour, N.M. (2009). Assessment of water resources quality at the southeastern part of the Nile Delta, Egypt. The international conference on water conservation in arid regions 12-14 October. Jeddah. Environmental Engineering, 7(10): 139-152.

ESDW (Egypt Standard for Drinking Water) (2007). Standards and specifications of water for drinking and domestic use. Decision of the Minister of Health and Population No. 458 (2007), Ministry of Health and Population, 10p. (In Arabic).

Gad, M. I., El-Kammar, M. M. and Ismail, H. M. G (2015). Groundwater Vulnrtability Assessment Using Different Overlay and Index Methods for Quaternary Aquifer of Wadi El-Tumilat, East Delta, Egypt. Asian Review of Environmental and Earth Sciences, 2(1): 9-22.

Goher, M.E., Hassan A.M., Abdel-Moniem, I.A., Fahmy, A.H. and El-Sayed S. M. (2014): Evaluation of surface water quality and heavy metal indices of Ismailia Canal, Nile River, Egypt. Egypt. J. Aquat. Res., 40, 225-233.

Geriesh, M.H., Balke, K. and El-Rayes, A.E. (2008). Problems of drinking water treatment along Ismailia Canal Province, Egypt. Journal of Zhejiang University Science B, 9(3): 232-242.

Khalaf, S. and Gad, M. I. (2015). Modeling of contaminant transport in 10th of Ramadan City Area, East Delta, Egypt. International Journal of Water Resources and and Environmental Engineering, 7(10): 139152.

Khalil, M. T., Amer, A. S., Sayed, M. M. and Nassif, M. G. (2012). Impact of pollution on macroinvertebrates biodiversity in Ismailia Canal, Egypt. Egypt. J. Aquat. Biol. \& Fish., 16 (4): 69-89.

Mandour, R. A., and Azab, Y. A. (2011). Toxic Levels of Some Heavy Metals in Drinking Groundwater in Dakahlyia Governorate, Egypt in the Year 2010. www.theijoem.com,April, 2(2): 112-117.

Meteoblue.com (2016). https://www.meteoblue.com/ar/weather/forecast. 
Moore, F., Attar, A. and Rastmanesh, F. (2011). Anthropogenic sources of heavy metals in deposited sediments from runoff and industrial effluents, Shiraz, SW Iran. 2nd International Conference on Environmental Science and Technology IPCBEE, (6): 215-219.

Mousavi, S. R., Balali-Mood, M., Riahi-Zanjani, B., Yousefzadeh, H. and Sadeghi, M. (2013). Concentrations of mercury, lead, chromium, cadmium, arsenic and aluminum in irrigation water wells and wastewaters used for agriculture in Mashhad, northeastern Iran. Journal of Occupational and Environmental Medicine, 4(2): 80-6.

Nair, G. A., Mohamed, A., \& Premkumar, K. (2005). Physico chemical parameters and correlation coefficients of ground waters of northeast Libya. Pollution Research, 24(1), 1.

Nour, H. E., El-Sorogy, A. S. and Abu El-Enain, F. M. (2013). Environmental Impacts Of Fertilizers Factories, Abou Zabal Area, Southern Sharkia Governorate Egypt. Journal of Applied Sciences Research, 9(7): 4142-4150.

Rajappa, B., Manjappa, S. and Puttaiah, E.T. (2010). Monitoring of heavy metal concentration in groundwater of Hakinaka Taluk, India. Contemporary Engineering Sciences, 3(4), 183-190.

Research institute for groundwater (RIGW), (1989). Hydrogeological map of Egypt, scale 1:100,000, 1st edition, map sheet of Cairo.

Safar, Z., Labib, M. W., Lotfi, W., and Khalil, M. H. (2014). Characterization of Contamination Around the Largest Lead Smelter in Egypt Carried Out Through a CooperationProgram between USA and Egypt. The journal of field actions, (7): 1-10.

Salem, H. M., Eweida, E. A. and Farag, A. (2000). Heavy Metals in Drinking Water and Their Environmental Impact on Human Health. ICEHM2000, Cairo University, Egypt, September, 542- 556.

Sharaky, A. M., Atta, S. A., El Hassanein A. S. and Khallaf K. M. A. (2007). Hydrogeochemistry Of Groundwater In The Western Nile Delta Aquifers, Egypt. 2nd International Conference on the Geology of Tethys, 19-21 March, Cairo University. 1-23. 
Stahl, R. and Ramadan A.B. (2008). Environmental Studies on Water Quality of the Ismailia Canal, Egypt. Scientific Report, Forschungszentrum Karlsruhe in der Helmholtz-Gemeinschaft Wissenschaftliche Berichte FZKA 7427, p. 58.

Taha, A. A., El-Mahmoudi, A. S. and El-Haddad, I. M. (2004). Pollution Sources And Related Environmental Impacts In The New Communities Southeast Nile Delta, Egypt. Emirates Journal for Engineering Research, 9(1): 35-49.

WHO (2011). Guidelines for Drinking-water Quality, Drinking water regulations and supporting policies and programs.

Yehia, M., Baghdady, A., Howari, F. M., Awad, S. and Gad, A. (2017). Natural radioactivity and groundwater quality assessment in the northern area of the Western Desert of Egypt. Journal of Hydrology: Regional Studies, 12, 331-344.

Yuce, G., Ugurluoglu, D., Dilaver, A.T., Eser, T., Sayin, M., Donmez, M., Ozcelik, S. and Aydin, F. (2009). The effects of lithology on water pollution: natural radioactivity and trace elements in water resources of Eskisehir region (Turkey). Water Air Soil Pollution, 202, 69-89.

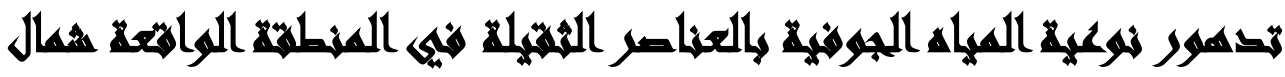 شرة المخاهرة - هصر}

[r]
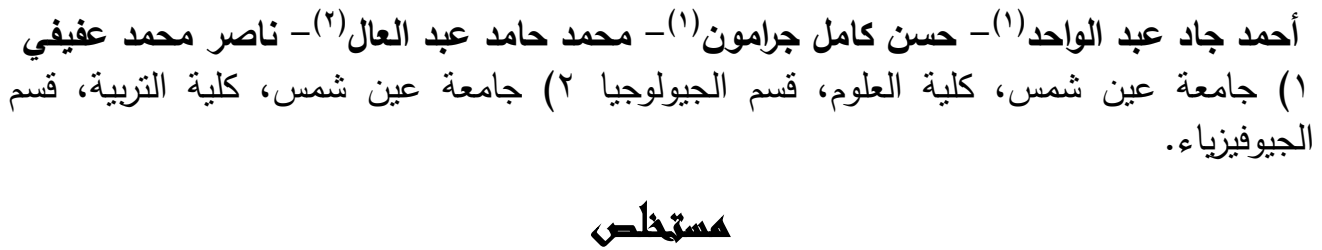

تستخدم المياه الجوفية في شمال شرق القاهرة للشرب والري والأغراض الصناعية. لذا لذائدي الأدي

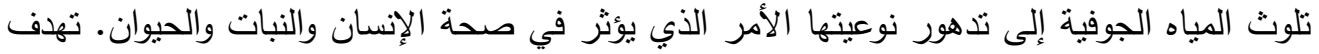

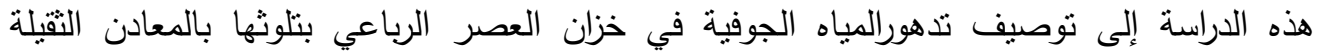

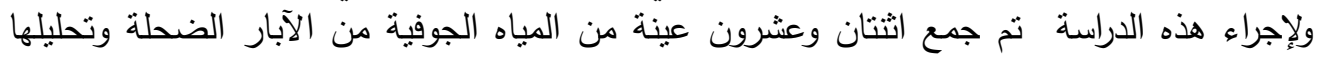


لتحديد نركيزات المعادن الثقبلة لمياه العينات التي تمت دراستها في المنطقة الواقعة بين أنشاص وأبو

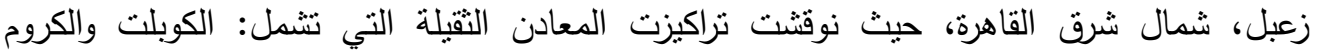

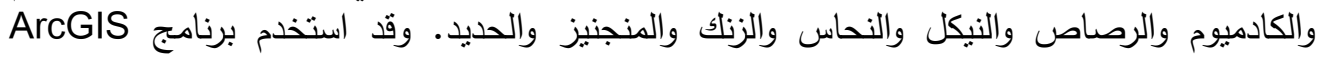

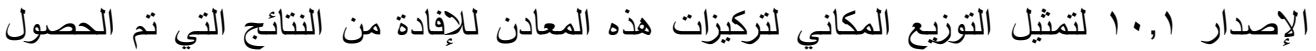
عليها من منطقة الدراسة.

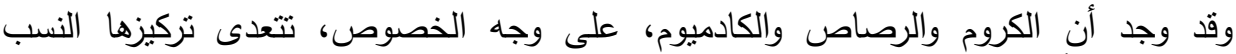

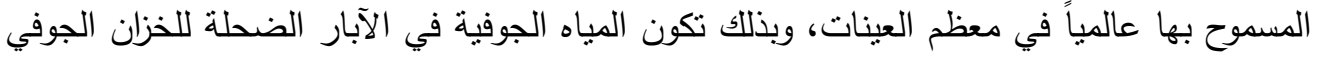

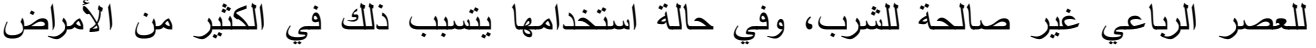

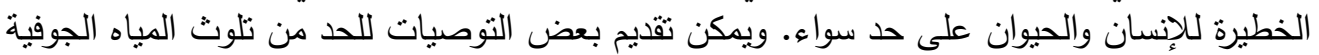

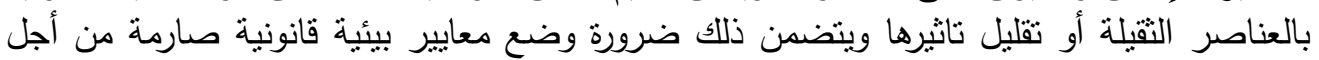

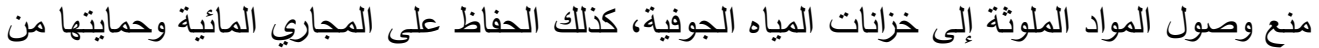

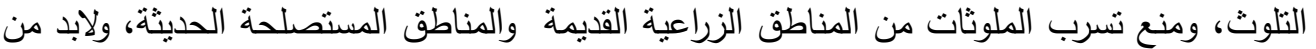

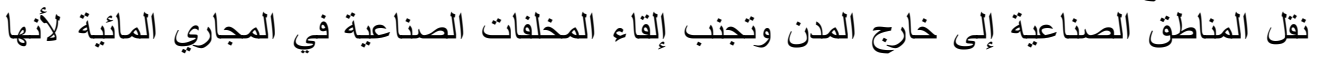

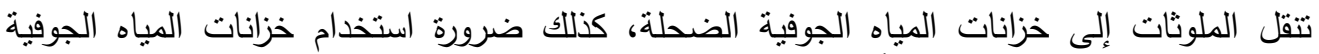
العميقة حيث بقل التلوث فيها بدلاً من الآبار السطحية. كذلك لوحظ أن هناك مصادر عديدة أخرى للتلوث في منطقة الدراسة تؤدي إلى تلى تدهور نوعية

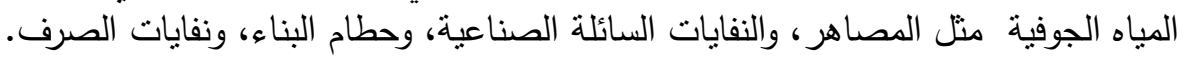

